\title{
SUBCRITYCALITY ANALYSIS OF HTR-10 SPENT FUEL CASK MODEL FOR THE 10 MW HTR INDONESIAN EXPERIMENTAL POWER REACTOR
}

\author{
Tagor Malem Sembiring ${ }^{1 *}$, Pungky Ayu Artiani ${ }^{2}$ \\ ${ }^{1}$ Center for Nuclear Energy Assesment, BATAN, Jalan Kuningan Barat, Mampang Prapatan, Jakarta, \\ 12710 \\ ${ }^{2}$ Center for Radioactive Waste Technology, BATAN, Kawasan PUSPIPTEK Serpong, Tangerang Selatan \\ 15310 \\ *E-mail: tagorms@batan.go.id
}

Diterima editor: 21 September 2018

Diperbaiki: 23 Oktober 2018

Disetujui untuk publikasi: 25 Oktober 2018

\begin{abstract}
SUBCRITICALITY ANALYSIS OF HTR-10 SPENT FUEL CASK MODEL FOR THE 10 MW HTR INDONESIAN EXPERIMENTAL POWER REACTOR. The $10 \mathrm{MW}$ HTR Indonesian Experimental Power Reactor (RDE reactor) is designed identical with the HTR-10 in China, conceptually. However, the review results showed that the spent fuel cask model which is used between two reactors is fully different, such as size and capacity. The proposed cask model in RDE reactor can hold 15 times more fuel pebbles than HTR-10 has. This research activities deal with the subcriticality analysis for the spent fuel cask of RDE reactor if using the HTR-10 cask model. The subcriticality condition is designed to meet the limit of safety value. The objective of this research is to determine the subcriticality value in the normal and accident events for the spent fuel cask when it is in the reactor building and the spent fuel cask room. All calculations were carried out by MCNP6.1 code. The selected external events are the water ingress (reactor room), water flood and the combination event of water flood and earthquake. The calculation results showed that the maximum value of $k_{\text {eff }}(3 \sigma)$ are 0.47510 and 0.19214 for the cask in the reactor building and in the spent fuel cask room, respectively. This value is far from the limit value of 0.95 . The calculation results showed that the spent fuel cask are in the safe condition eventhough in the worst combination events, the cask is flooded and earthquake. The HTR-10 spent fuel cask can be proposed as an alternative for the RDE reactor to get an efficient reactor building.
\end{abstract}

Keywords: spent pebble fuel element, HTGR, subcriticality, MCNP6.1, RDE reactor

\begin{abstract}
ABSTRAK
ANALISIS SUBKRITIKALITAS PENYIMPAN BAHAN BAKAR BEKAS MODEL CASK REAKTOR HTR-10 UNTUK REAKTOR DAYA EKSPERIMENTAL 10 MW TERMAL. Reaktor Daya Eksperimental (RDE) secara konseptual didesain identik dengan reaktor HTR-10 di Tiongkok. Meskipun demikian, terdapat perbedaan yang signifikan untuk desain konseptual cask penyimpan bahan bakar bekas di kedua reaktor seperti dimensi dan kapasitas. Kegiatan penelitian ini berkaitan dengan analisis subkritikalitas cask penyimpan elemen bahan bakar bekas tipe pebble di RDE jika menggunakan model cask yang dipakai di HTR-10. Kondisi sub-kritikalitas didesain memenuhi nilai batas keselamatan. Tujuan penelitian adalah menentukan nilai subkritikalitas dalam keadaan normal atau kondisi kecelakaan di gedung reaktor dan di gudang penyimpan bahan bakar bekas. Perhitungan dilakukan dengan paket program MCNP6.1. Kejadian kecelakaan yang dipilih adalah masuknya air ke dalam cask, cask terendam air dan kombinasi cask terendam air dan kejadian gempa. Hasil perhitungan menunjukkan bahwa nilai maksimum $k_{\text {eff }}(3 \sigma)$ untuk cask di gedung reaktor dan di gudang penyimpan bahan bakar bekas masing-masing adalah 0,47510 dan 0,19214. Nilai ini masih jauh dari batas 0,95. Hasil perhitungan menunjukkan bahwa cask penyimpan bahan bakar bekas tetap dalam keadaan selamat meski terjadi kombinasi 2 kejadian eksternal.
\end{abstract}

Kata kunci: elemen bahan bakar bekas tipe pebble, HTGR, subkritikalitas, MCNP6.1, RDE

DOI: $10.17146 / \mathrm{tdm} \cdot 2018.20 .3 .4630$ 


\section{INTRODUCTION}

Construction of the 10 MW HTR Indonesian Experimental Power Reactor, named Reaktor Daya Experimental (RDE) is a priority program of BATAN to be used as a R\&D facility nuclear energy, besides to get a high public acceptance for the first nuclear power plant in Indonesia $[1,2]$. RDE reactor is a $10 \mathrm{MW}$ (thermal) High Temperature Gas-cooled Reactor (HTGR) using TRISO pebble bed fuel element [3]. The power of $10 \mathrm{MW}$ is generated by 27,000 fuel pebbles with the multi-pass fuel loading scheme. 25 fresh fuel pebbles are loaded with each fuel pebble will pass through the reactor core five times (in average) before it will be discharged to the spent fuel cask. It means, 25 fuel pebbles are sent to the cask per day or 9,000 fuel pebbles per year [3]. By this specification, RDE is identic with the HTR-10 reactor in China [4-6].

The conceptual design document of RDE show the size of spent fuel cask proposed by RENUKO is different from that used in the HTR-10 [3,7]. The main difference is capacity, the submitted design is 30,000 fuel pebbles but the HTR-10 cask is 2,000 fuel pebbles. The difference has an impact on the area that has to be provided in the reactor building and spent fuel storage room. The crane and transportations system should be fixed with the cask size. RENUKO decided to adopt the cask for fulfilling the requirement of resistance from the external hazard of the aircraft crash.

The spent fuel cask with smaller volume will reduce the area and the cask handling is more efficient. The idea to apply the HTR-10 cask in the RDE is needed to be carried out. The objective of this research is to analyze the subcriticality of the cask in the reactor building and the spent fuel storage room (SFSR) with normal and accident conditions. The influence on the SFSR will be discussed.

The results of this study are useful for the basic and detail design of RDE, specifically for the spent fuel management/handling system, the reactor layout and the SFSR. The study was conducted by using the MCNP6.1 code with the ENDF/B-VII.1 nuclear library [8-10]. This code has been verified and validated with various cases and types of reactors that showed the satisfactory results $[11,12]$. The criticality conditions were carried out for 3 accident conditions, i.e. water ingress (cask), the cask is flooded and the combination of water flood and earthquake.

\section{DESCRIPTION OF RDE AND HTR-10 SPENT FUEL CASKS}

The spent fuel cask (SFC) of RDE is designed conceptually based on the PWR spent fuel cask technology [3]. The SFC is designed resistance with the external event of aircraft crashes. The SPF is able to store an average of 30,000 fuel pebbles with the length and outer diameter of 7,000 $\mathrm{mm}$ and 2,500 $\mathrm{mm}$ [3], respectively. The time required for the SFC to be full of fuel pebbles is 1,200 effective full power days (EFPD). With this size, the SFC can accommodate the maximum number of 45,000 fuel pebbles [3]. When the SFC is full, then transferred to the SFSR located outside the reactor building. The detail information of the HTR-10 spent fuel cask can be seen in [7]. Table 1 shows the comparison between the RDE and HTR-10 spent fuel casks.

Table 1. Dimension and material for the RDE and HTR-10 spent fuel casks [3, 7].

\begin{tabular}{ccc}
\hline & & \\
Parameters & Designed RDE cask & HTR-10 cask \\
\cline { 2 - 3 } & 7 & 2.1 \\
Total height, $\mathrm{m}$ & 2.5 & 0.878 \\
Outer diameter, $\mathrm{m}$ & - & 0.606 \\
Inner diamater,m & 30,000 & 2,000 \\
Average capacity, pebble & Modular cast iron (GGG 40.3) & Modular cast iron (GGG 40.3) \\
Main material & Thick steel mixed with boron & Thick steel with lead \\
Shielding &
\end{tabular}

The different cask dimensions caused the specification of the SFSR is different, too. The specification can be shown in the Table 2. The SFSR should be able to accommodate the 40 years 
operation of RDE, then a total of 16 and 200 casks are needed for RDE and HTR-10 reactors, respectively. As a result, the space needed for the RDE reactor is $300 \mathrm{~m}^{2}$ while the HTR-10 requires an area of $400 \mathrm{~m}^{2}$. However, the minimum height required for RDE is $7 \mathrm{~m}$ and for HTR-10 is $2.1 \mathrm{~m}$.

Table 2. Comparison spent fuel storage room for RDE and HTR-10 [3, 7].

\begin{tabular}{|c|c|c|}
\hline \multirow{2}{*}{ Parameters } & \multicolumn{2}{|c|}{ Value } \\
\hline & Concpetual design of RDE & HTR-10 \\
\hline Coolant & Natural and force convection & Natural and force convection \\
\hline Shielding & concrete & concrete \\
\hline Inner/Outer diameter of shielding, $\mathrm{m}$ & - & $1 / 1.3$ \\
\hline Height of shielding,m & - & 1.8 \\
\hline Capacity, casks & 16 & 204 \\
\hline Surface temperatur of cask, ${ }^{\circ} \mathrm{C}$ & 80 & 60 \\
\hline Heat per cask, kW & 19 & 1.9 \\
\hline $\begin{array}{l}\text { Number of cask for } 40 \text { years } \\
\text { operation }\end{array}$ & 16 & 200 \\
\hline Area, $\mathrm{m} \times \mathrm{m}$ & $12 \times 25$ & $20 \times 20$ \\
\hline
\end{tabular}

\section{METHODOLOGY}

All subcriticality calculations were carried out using the MCNP6.1 code, all program packages. The fuel kernels with TRISO coated particles and pebble fuel elements are modeled with detailed 3-dimensional geometry. The spent fuel cask is modeled based on the following conditions:

a. Dimensions of cask:

1. If we assumed the packing fraction of pebbles in the cask is 0.61 , the volume of 1 fuel pebble is $185.4055 \mathrm{~cm}^{3}$

2. The capacity cask is 2,000 pebbles, so the inner volume of the cask is $370,810.9 \mathrm{~cm}^{3}$

3. We assumed that the bottom or upper part of the cask is $1 / 2$ sphere

4. Inner radius cask is $30.3 \mathrm{~cm}$, so the area of the cask is $116,5243.3 \mathrm{~cm}^{3}$

5. The volume of bottom or upper part is $4 / 3 \times \pi \times(30,3 \mathrm{~cm})^{3}=116.524,3 \mathrm{~cm}^{3}$

6. The volume of cylinder part is $370,810.9 \mathrm{~cm}^{3}-116,524.3 \mathrm{~cm}^{3}=254,286.6 \mathrm{~cm}^{3}$

7. The height of cylinder part is $254,286.6 \mathrm{~cm}^{3} / 2,884.265 \mathrm{~cm}^{2}=88.16342 \mathrm{~cm}$

b. Thickness of $\mathrm{Pb}$ (lead)

Ref [7] showed that cask is placed between two layers of stainless steel (SS). The thickness of $\mathrm{Pb}$ depends on the thickness of SS. SS material used is modular cast iron (GGG 40.3) with a composition of $3.70 \mathrm{w} / \mathrm{o} \mathrm{C}, 2.50 \mathrm{w} / \mathrm{o} \mathrm{Si}, 0.4 \mathrm{Mn}$, and the rest is Fe. Total thickness of the cask is $13.6 \mathrm{~cm}$ [7] so that, if divided by 3 , the thickness is $13.6 \mathrm{~cm} / 3$ or $4,5333 \mathrm{~cm}$, so it is assumed that the minimum $\mathrm{Pb}$ thickness is $4,5333 \mathrm{~cm}$. Then, the thickness of SS inside is varied up to $0.5 \mathrm{~cm}$ or identical making thick $\mathrm{Pb}$ increase until it reaches a maximum thickness of $8.5667 \mathrm{~cm}$. Therefore, the effect of $\mathrm{Pb}$ thickness on the criticality calculations is carried out. Table 3 shows the variation of $\mathrm{Pb}$ thickness used in this study.

Table 3. Variasi tebal $\mathrm{Pb}$ cask penyimpan EBBB.

\begin{tabular}{cccc}
\hline & $\begin{array}{c}\text { Outer thickness of SS, } \\
\text { cm }\end{array}$ & $\begin{array}{c}\text { Thickness of Pb, } \\
\text { cm }\end{array}$ & $\begin{array}{c}\text { Inner thickness of SS, } \\
\text { cm }\end{array}$ \\
\hline Thickness-1 & 4.5333 & 4.5333 & 4.5333 \\
Thickness-2 & 4.5333 & 5.0333 & 4.0333 \\
Thickness-3 & 4.5333 & 5.5667 & 3.5 \\
Thickness-4 & 4.5333 & 6.0667 & 3.0 \\
Thickness-5 & 4.5333 & 6.5667 & 2.5 \\
Thickness-6 & 4.5333 & 7.0667 & 2.0
\end{tabular}




\begin{tabular}{cccc}
\hline & $\begin{array}{c}\text { Outer thickness of SS, } \\
\text { cm }\end{array}$ & $\begin{array}{c}\text { Thickness of Pb, } \\
\text { cm }\end{array}$ & $\begin{array}{c}\text { Inner thickness of SS, } \\
\text { cm }\end{array}$ \\
\hline Thickness-7 & 4.5333 & 7.5667 & 1.5 \\
Thickness-8 & 4.5333 & 8.0667 & 1.0 \\
Thickness-9 & 4.5333 & 8.5667 & 0.5 \\
\hline
\end{tabular}

The kernel particles are modeled by simple cubic (SC) while the fuel pebble is model by the body-centered cubic (BCC). Table 4 shows the input parameter for the MCNP calculations. The calculations were carried out for 9 thickness of $\mathrm{Pb}$ (Table 3). All nuclides were taken from the ENDF/B-VII.1 file (zaid .80c) [9]. The thermal scattering treatments are from graphite (grph) and graphite and water (lwtr) for normal and accident conditions, respectively. The floor with the thickness of $30 \mathrm{~cm}$ is chosen for this calculation.

Table 4. MCNP input for cariticality calculation.

\begin{tabular}{lcc}
\hline \multicolumn{1}{c}{ Parameters } & \multicolumn{2}{c}{ Criticality Calculation } \\
\cline { 2 - 3 } & Reactor Building & Spent Fuel Storage Facility \\
\hline Neuton per cycle & 10000 & 10000 \\
Total cycles & 400 & 400 \\
Skipped cycle & 100 & 100 \\
Neutron source card & ksrc & $\mathrm{ksrc}$ \\
Calculation mode & $\mathrm{n}$ & $\mathrm{n}$ \\
$S(\alpha, \beta)$ & grph and lwtr & grph and lwtr \\
\hline
\end{tabular}

Criticality analysis is carried out for normal and accident conditions. The conservative criticality values are chosen to assume the fresh fuel (fuel burn-up is $0 \%$ ) are in the cask. Table 5 shows 3 selected accident conditions with one event which is a combination of two events. The first accident is water ingress. The water ingress in the cask occurred if the isolation valve is not working when the water ingress occurred in the core. We assumed that there is no water ingress in the SFSR. The second accident of water flood occurred in the reactor building and SFSR. The third accident is the combination of 2 events of water flood and earthquake. The combination event is assumed to occur in both of reactor building and SFSR. Criticality value, $k_{\text {eff }}$, for all conditions must be less than 0.95 with a standard deviation of $3 \sigma$. We assumed that the higher fuel compaction of $21.3 \%$ resulted when the earthquake event.

Table 5. Selected events for criticality analysis of spent fuel cask.

\begin{tabular}{lcc}
\hline \multicolumn{1}{c}{ Postulated events } & \multicolumn{2}{c}{ Criticality Calculation } \\
\cline { 2 - 3 } & Reactor building & Spent fuel storage facility \\
\hline Water ingress & Yes & No \\
Water flood & Yes & Yes \\
Water flood and earthquake & Yes & Yes \\
\hline
\end{tabular}

\section{RESULTS AND DISCUSSIONS}

\section{MCNP model of cask}

As mentioned earlier, the number of the cask in the reactor building and the SFSR are 1 cask and 200 casks $(10 \times 20$ cask $)$ respectively. Figures 1 and 2 show the detail MCNP model for the cask in the reactor building and the SFSR. Figure 1 shows the MCNP model has conformity with the technical drawing of the cask. The configuration of 200 casks, $10 \times 20$, is also successfully modeled as shown in Fig. 2, of the detailed MCNP6.1 modeling that is in accordance with the original image. Figure 1 also shows that cask filled by 2,000 fresh pebble fuel elements. Figure 2 shows the configuration of 200 casks, $10 \times 20$, also successfully modeled in detail with MCNP. 


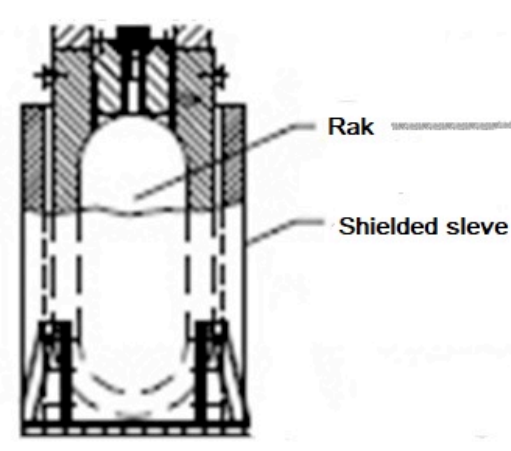

(a)

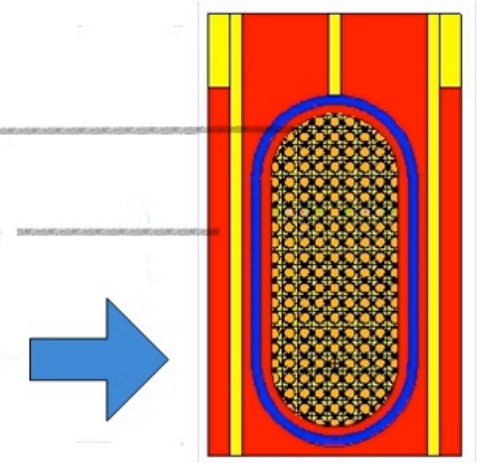

(b)

Figure 1. Technical drawing (a) [5] MCNP model (b) of cask.

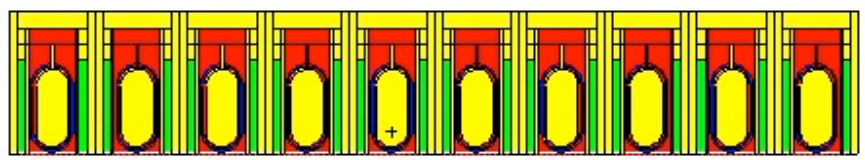

(a)

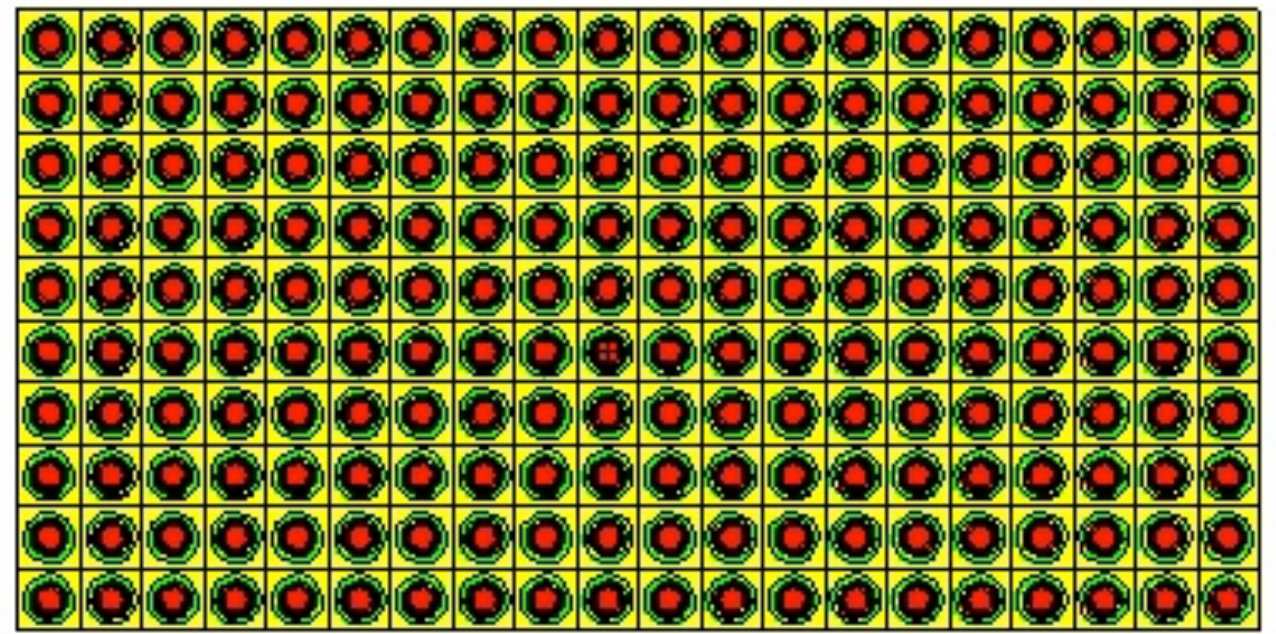

(b)

Figure 2. The cask configuration in the SFSR, vertical view (a) and horizontal view (b).

\section{Criticality analysis in the reactor building}

The criticality calculation results of cask in the reactor building for normal and 3 postulated accident events are shown in Table 6 . The calculation results show that the $k_{\text {eff }}$ will increase with the increment of $\mathrm{Pb}$ thickness, for all conditions. The $k_{\text {eff }}$ increased by $16 \%, 1.6 \%, 1.6 \%$ and $2.4 \%$ for normal condition, water ingress, water flood and the combination of the water flood and earthquake. This is due to the thickness of inner SS is thinner if the $\mathrm{Pb}$ is thicker, so the neutron absorption rate of Fe in SS decreased. The calculation results prove that the $k_{\text {eff }}$ increase sensitively in the normal conditions.

Table 6 also shows that the criticality for the water ingress has a higher effect than the water flood. This can be seen from the calculated $k_{\text {eff }}$ is higher than $0.6 \%$, although $0.6 \%$ difference is significant because it is larger than $3 \sigma$. The combination event, water flood and earthquake, is the postulated event that gives a highest increment of $\mathrm{k}_{\text {eff }}$ among those postulated events. This is 
indicated by the difference of $20 \%$ for $k_{\text {eff }}$ of the each event compare with the water ingress event. It should be noted that if the maximum value of $3 \sigma$ is taken, the $k_{\text {eff }}$ value will increase by $191 \%$, $189 \%$ and $251 \%$ respectively for the water ingress, water flood and the combination event, compared with the average $k_{\text {eff }}$ of normal condition.

The maximum calculated $k_{\text {eff }}$ is $0.4746(3 \sigma)$ but this value is still far from the limit value of 0.95 . When compared with the normal conditions, the value is up 2.5 times, which indicates that the selected combination event is significant enough to increase the criticality condition of the cask. The calculation results also show that the fuel compaction from the earthquake gives a maximum contribution on the $k_{\text {eff }}$ only 0.08495 . Therefore, the contribution of water, water ingress or water flood, which contributes considerably in the criticality of the cask.

Table 6. Calculated $k_{\text {eff }}$ for cask in reactor building with normal and 3 postulated events.

\begin{tabular}{|c|c|c|c|}
\hline & $\begin{array}{c}\text { Thickness of } \\
\text { Pb, cm }\end{array}$ & $\mathbf{k}_{\text {eff }}$ & deviation $(3 \sigma)$ \\
\hline \multicolumn{4}{|c|}{$\begin{array}{l}\text { Normal condition } \\
\end{array}$} \\
\hline Thickness-1 & 4.5333 & 0.11658 & 0.00041 \\
\hline Thickness-2 & 5.0333 & 0.11702 & 0.00043 \\
\hline Thickness-3 & 5.5667 & 0.11771 & 0.00045 \\
\hline Thickness-4 & 6.0667 & 0.11812 & 0.00044 \\
\hline Thickness- 5 & 6.5667 & 0.12005 & 0.00044 \\
\hline Thickness- 6 & 7.0667 & 0.12143 & 0.00040 \\
\hline Thickness-7 & 7.5667 & 0.12364 & 0.00043 \\
\hline Thickness- 8 & 8.0667 & 0.12799 & 0.00049 \\
\hline Thickness-9 & 8.5667 & 0.13523 & 0.00046 \\
\hline \multicolumn{4}{|c|}{ Postulated event- 1: water ingress } \\
\hline Thickness-1 & 4.5333 & 0.38646 & 0.00050 \\
\hline Thickness-2 & 5.0333 & 0.38639 & 0.00052 \\
\hline Thickness-3 & 5.5667 & 0.38648 & 0.00048 \\
\hline Thickness-4 & 6.0667 & 0.38675 & 0.00045 \\
\hline Thickness-5 & 6.5667 & 0.38672 & 0.00050 \\
\hline Thickness- 6 & 7.0667 & 0.38754 & 0.00052 \\
\hline Thickness-7 & 7.5667 & 0.38796 & 0.00048 \\
\hline Thickness- 8 & 8.0667 & 0.38986 & 0.00052 \\
\hline Thickness-9 & 8.5667 & 0.39248 & 0.00050 \\
\hline \multicolumn{4}{|c|}{ Postulated event-2: water flood } \\
\hline Thickness-1 & 4.5333 & 0.38405 & 0.00049 \\
\hline Thickness-2 & 5.0333 & 0.38390 & 0.00049 \\
\hline Thickness-3 & 5.5667 & 0.38419 & 0.00047 \\
\hline Thickness-4 & 6.0667 & 0.38427 & 0.00052 \\
\hline Thickness-5 & 6.5667 & 0.38426 & 0.00048 \\
\hline Thickness-6 & 7.0667 & 0.38489 & 0.00049 \\
\hline Thickness-7 & 7.5667 & 0.38584 & 0.00049 \\
\hline Thickness- 8 & 8.0667 & 0.38727 & 0.00051 \\
\hline Thickness-9 & 8.5667 & 0.39013 & 0.00048 \\
\hline \multicolumn{4}{|c|}{$\begin{array}{l}\text { Postulated event-3: water flood and earthquake } \\
\end{array}$} \\
\hline Thickness-1 & 4.5333 & 0.46251 & 0.00114 \\
\hline Thickness-2 & 5.0333 & 0.46345 & 0.00105 \\
\hline Thickness-3 & 5.5667 & 0.46332 & 0.00120 \\
\hline Thickness-4 & 6.0667 & 0.46371 & 0.00133 \\
\hline Thickness-5 & 6.5667 & 0.46354 & 0.00167 \\
\hline Thickness- 6 & 7.0667 & 0.46409 & 0.00112 \\
\hline Thickness-7 & 7.5667 & 0.46637 & 0.00085 \\
\hline Thickness- 8 & 8.0667 & 0.46821 & 0.00137 \\
\hline Thickness-9 & 8.5667 & 0.47338 & 0.00122 \\
\hline
\end{tabular}




\section{Criticality analysis in the SFSR}

Table 7 shows the $\mathrm{k}_{\text {eff }}$ of cask in the SFSR for normal and 2 postulated events. Unlike in the reactor building, the water ingress event is not taken into account because all the casks are closed.

The calculation results in Table 7 show the same trend as the calculation results in the reactor building that the $k_{\text {eff }}$ of cask will increase with the thicker. Table 7 showed the $k_{\text {eff }}$ increased into $14.6 \%$. $11.5 \%$ and $10.3 \%$ for the normal conditions, the water flood and the combination of 2 events, respectively. Although the increment of $k_{\text {eff }}$ is smaller than in the reactor building for the normal conditions, however on the contrary it is greater for the combination of 2 events. The contribution of concrete shielding and moderator ratio around the cask influences the criticality of the cask.

Table 7. Calculated criticality of cask in SFSR.

\begin{tabular}{|c|c|c|c|}
\hline & $\begin{array}{c}\text { Thickness of } \\
\text { Pb, cm }\end{array}$ & $\mathbf{k}_{\text {eff }}$ & deviation $(3 \sigma)$ \\
\hline \multicolumn{4}{|c|}{ Normal condition } \\
\hline Thickness-1 & 4.5333 & 0.12472 & 0.00043 \\
\hline Thickness-9 & 8.5667 & 0.14293 & 0.00046 \\
\hline \multicolumn{4}{|c|}{ Postulated event-2: water flood } \\
\hline Thickness-1 & 4.5333 & 0.10806 & 0.00039 \\
\hline Thickness-9 & 8.5667 & 0.12044 & 0.00047 \\
\hline \multicolumn{4}{|c|}{ Postulated event-3: water flood and earthquake } \\
\hline Thickness-1 & 4.5333 & 0.17233 & 0.00188 \\
\hline Thickness-9 & 8.5667 & 0.19016 & 0.00198 \\
\hline
\end{tabular}

Table 7 also shows that the calculated $k_{\text {eff }}$ decreased for the water flood event compared to the normal conditions in the range of $13.4 \%-15.7 \%$. This is contrast with what occurred in the reactor building because the cask configuration made the over-moderated condition so that when the water is more, it will decrease the $k_{\text {eff. }}$ However, for the combination of 2 events, the calculated $k_{\text {eff }}$ is higher than normal conditions in the range of $33 \%-38.2 \%$. The contribution of the fuel compaction to the $k_{\text {eff }}$ is more than $57.9 \%-59.5 \%$. This shows the effect of the earthquake significantly influences the criticality in the SFSR. The maximum $k_{\text {eff }}$ of the cask is $0.19214(3 \sigma)$ for the combination of 2 events, but this value is far from the limit value of 0.95 .

\section{CONCLUSIONS}

The calculation results of MCNP6.1 code show that subcriticality of spent fuel cask can be maintained even in the combination 2 postulated accident events, water flood and earthquakes. The maximum sub-criticalities for the casks $(3 \sigma)$ are 0.47510 and 0.19214 in the reactor building and the spent fuel storage room (SFSR), respectively. Those values are below the limit value of 0.95 . The cask of HTR-10 reactor can be applied in the RDE considering the reactor core and the fuel specification used are the same as the HTR-10 reactor.

\section{ACKNOWLEDGEMENT}

The authors would like to thank Mr. Zuhair (PTKRN-BATAN) for his helpful advice on the modeling the kernel particles and fuel pebbles. This research work is the part of RDE project in the PKSEN-BATAN and PTLR-BATAN funded by the DIPA 2018. 


\section{REFERENCES}

1. Liem P.H.. Sembiring T.M.. Arbie B.. Subki I. Analysis of the optimal fuel composition for the Indonesian experimental power reactor. Kerntechnik. 2017. 82(1):78-86

2. Husnayani I.. Udiyani P.M. Radionuclide characteristics of RDE spent fuels. Tri Dasa Mega. 2018. 22(3):69-76.

3. RENUKO Fuel Handling and Storage - Conceptual Design. RDE/DS-WBS02-210. Jakarta: 2015.

4. Wu Z.. Lin D.. Zhong D. The design features of HTR-10. Nuclear Engineering and Design. 2002. 218:25-32

5. Liem P.H. Sembiring T.M.. Tran H.N. Evaluation on fuel cycle and loading scheme of the Indonesian experimental power reactor (RDE) design. Nuclear Engineering and Design. 2018. 340:245-259

6. Liem P.H.. Tran H.N.. Sembiring T.M.. Arbie B.. Subki I. Alternative Fueling Scheme for the Indonesian Experimental Power Reactor (10 MWth Pebble-Bed HTGR). Energy Procedia. 2017. 131:69-76

7. Wang J.H.. Huang Y.F.. Tang Y.. Wu B. Natural safety analysis of the spent fuel residual heat removal in loading and storage process of HTR-10. Energy Procedia. 2013. 39:227-39

8. Goorley T.. James M.. Booth T.. Brown F.. Bull J.. Cox L.J.. et al. Features of MCNP6. Ann. Nucl. Energy. 2016. 87:772-83.

9. Marck S.C. Van Der Benchmarking ENDF/B-VII.1. JENDL-4.0 and JEFF-3.1.1 with MCNP6. Nucl. Data Sheets. 2012. 113(12):2935-3005.

10. Kahler A.C.. MacFarlane R.E.. Chadwick M.B. Integral data testing of ENDF/B-VII.1 files - success stories and need to improve stories. Nucl. Data Sheets. 2014. 118(1):410-3.

11. Abrefah R.G.. Birikorang S.A.. Nyarko B.J.B.. Fletcher J.J.. Akaho E.H.K. Design of serpentine cask for Ghana research reactor-1 spent nuclear fuel. Prog. Nucl. Energy. 2014. 77:84-91.

12. Artiani P.A.. Heriyanto K. Analisis sub-kritikalitas rak bahan bakar nuklir bekas RSG-GAS menggunakan aluminium. Urania 2017. 23(2):127-38. 